\title{
JOURNAL.RU
}



Ероклинцев В.Н. ${ }^{1}$, Лукьянова В.О. ${ }^{1}$

${ }^{l}$ СТТУ им. Ю.А.Гагарина

${ }^{2}$ СГАУ им.Н.И. Вавилова

Саратов, Россия

doi: $10.18411 / 1 \mathrm{j}-31-07-2017-22$

idsp 000001:1j-31-07-2017-22

\section{Исследование антибактериального эффекта на образцах медицинской нержавеющей стали марки 12X18Н10Т}

Научные руководители: Анников В.В. ${ }^{2}$, Пичхидзе С.Я. ${ }^{1}$

Ежедневно для проведения различного вида операций используют медицинские инструменты, изготовленные из медицинских сплавов. Поскольку такие инструменты являются многоразовыми, после каждого их использования требуется проводить поверхностную стерилизацию и дезинфекцию инструментов [Ошибка! Источник ссылки не найден.], такой процесс необходим для предотвращения заражения последующих пациентов бактериальными инфекциями. Вследствие этого, необходимо создания антибактериальных покрытий [2-3].

Цель настоящей работы: исследовать образцы медицинской нержавеющей стали марки $12 \mathrm{X} 18 \mathrm{H} 10 \mathrm{~T}$ с различными видами обработки на наличие антибактериального эффекта.

Объекты и метод исследования: образцы представляли собой пластины медицинской нержавеющей стали марки 12Х18Н10Т по ТУ 3-1002-77. Далее образцы подвергались пескоструйной обработкой электрокорундом Al2O3, электрополированием, пассивацией и термическим оксидированием (Рис.1 (a)).

Для оценки антимикробной активности использовались микроорганизмы: Escherichia coli 4295 (O:26) и Staphylococcus aureus ATCC-6538 (FDA 209-P), предоставленные государственной коллекцией патогенных бактерий ФКУЗ РосНИПЧИ «Микроб» Роспотребнадзора г. Саратова в 2016 г. Для определения 
устойчивости к антибактериальным препаратам применялся клинический изолят Pseudomonas aeruginosa (синегнойная палочка, грамотрицательная бактерия). На рис.1 показано распределение взвеси на образцах, подвергшиеся пескоструйной обработке электрокорундом A12O3, электрополированию и пассивации. Взвесь микроорганизмов равномерно распределилась по всей поверхности чашки со всеми образцами, сами образцы чистые и вокруг образцов есть защитный барьер 1-2 mm, не дающий микроорганизмам развиваться.

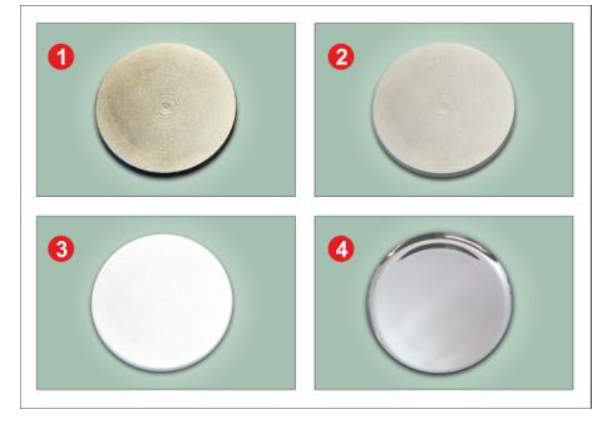

a)

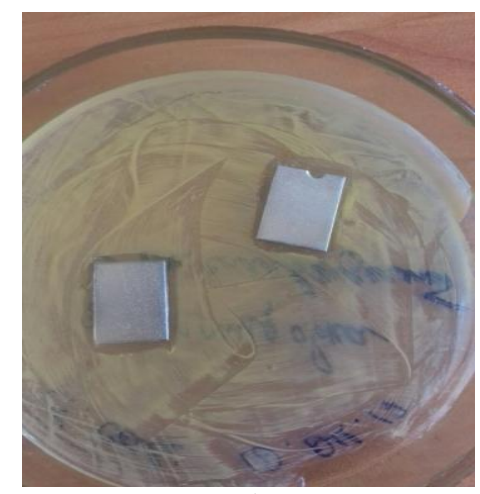

б)

Pис.1. (а) Внешний вид образиов стали марки 12Х18Н10T, где: 1 - пластины без покрытия; 2 - пластины обработаны электрокорундом Al2O3; 3 - пластины отпескоструены электрокорундом Al2O3, электроотполированы и пассивированы; 4-пластины с термическим оксидированием; (б) изображения распределения взвеси на образцах стали 12 X18H10Т после пескоструйной обработки Al2O3, электрополирования и пассивации

Подобное распределение взвеси микроорганизмов указывает на то, что пластины, которые подверглись не только пескоструйной обработкой электрокорундом A12O3, но электрополированием и пассивацией, а также образцов с термическим оксидированием, имеют антибактериальный эффект.

Вывод: для формирования антибактериального оксидного покрытия на медицинской нержавеющей стали марки 12X18Н10T, состоящего из смеси оксидов металлов $(\mathrm{Cr}, \mathrm{Ni}, \mathrm{Fe}, \mathrm{Ti}, \mathrm{Cu})$, целесообразно применять пассивацию.

1. Сэндл Т. Механизмы бактериальной адгезии // Чистые помещения и технологические среды. - 2014. -№ 1 (49). - С 54-58.

2. Zilberman M., Elsner J. J. Antibiotic-eluting medical devices for various application // Journal of Controlled Release. - 2008. - Vol. 130. №. 3. - P. 202-215.

3. Rai M., Yadav A., Gade A. Silver nanoparticles as a new generation of antimicrobials . Biotechnology advances. - 2009. - Vol. 27. - №. 1. - P. 76-83. 